\title{
FOTOGRAMETRIA COMO BASE PARA 0 RECONHECIMENTO DE CRONOLOGIAS URBANAS E ARQUITETÔNICAS
}

Photogrammetry as a basis for the recognition of urban and architectural chronologies

\section{Ana Teresa Cirigliano Villela' e Rodrigo Luiz Minot Gutierrez'}

RESUMO: O tema deste artigo é o uso da fotogrametria associada a pesquisas históricodocumentais, tomando como caso de estudo o reconhecimento da cronologia de formação e transformação do perfil edificado em volta da Praça XV de Novembro e da Praça Carlos Gomes, localizadas no Quadrilátero Central de Ribeirão Preto (SP). Trata-se do conjunto onde a cidade foi fundada e que vem sendo modificado desde sua origem, em 1856, aos dias atuais. Os documentos fotográficos, cartográficos e textuais disponíveis capturam fragmentos da área com grandes lacunas temporais e, por isso, o reconhecimento cronológico das transformações urbanas e arquitetônicas da área solicita a exploração da própria matéria edificada como fonte informativa. Para tanto, foi realizado um exercício experimental de observação, organização e representação de dados obtidos por meio de documentos existentes (fotos e mapas) e pela Fotogrametria terrestre, com vistas a apresentar uma proposta metodológica de levantamento das edificações e verificar os resultados obtidos.

PALAVRAS-CHAVE: Representações; Cronologia urbana; Metodologia de documentação.

\begin{abstract}
The theme of this article is the use of photogrammetry associated to historicaldocumentary researches, taking as a study case the recognition of the chronology of formation and transformation of the profile built around Praça XV de Novembro and Praça Carlos Gomes, located in the Quadrilátero Central of Ribeirão Preto (SP). It is the set where the city was founded and that has been modified from its origin, in 1856, to the present days. The available photographic, cartographic and textual documents capture fragments of the area with large temporal gaps and, for this reason, the chronological recognition of the urban and architectural transformations of the area calls for the exploration of the very matter built up as an information source. For that, an experimental exercise was carried out to observe, organize and represent data obtained through existing documents (photos and maps) and by terrestrial Photogrammetry, with a view to presenting a methodological proposal for surveying the buildings and verifying the results obtained.
\end{abstract}

KEYWORDS: Representations; Urban Chronology; Documentation Methodology.
How to cite this article:

VILLELA, A. T. C.; GUTIERREZ, R. L. M. Fotogrametria como base para o reconhecimento de cronologias urbanas e arquitetônicas. .Gestão e Tecnologia de Projetos, São Carlos, v.15, n.1, p.9-25, jan.2020. http://dx.doi.org/10.11606/ gtp.v14i1.149148
Fonte de financiamento:

Declara não haver

Conflito de interesse:

Sublara não haver

Submetido em: 20/08/2018

Aceito em: 13/08/2019 


\section{A DOCUMENTAÇÃO DE ARQUITETURAS E PAISAGENS HISTÓRICAS}

"Documentar é um processo cuja finalidade é a descrição detalhada do que se pretende estudar ou inventariar, produzindo um conjunto de dados do qual se possa extrair informações e conhecimento" (KOATZ et al., 2008, p. 1). Sendo um dos objetivos da documentação, o inventário, por sua vez, pode ser entendido como um processo por meio do qual se elucidam as características materiais e históricas de um dado edifício, que podem justificar (ou não) seu reconhecimento enquanto patrimônio. "Surgiram como modos de produzir um novo saber, por meio da coleta e sistematização de informações obedecendo a determinado padrão e repertório de dados passíveis de análises e classificações.” (MOTTA; SILVA, 2016, p. 2). Tal processo é condicionado, em primeiro lugar, pela noção de patrimônio, em constante ampliação, e, em segundo, pelo desenvolvimento e disponibilidade de novas tecnologias (MOTTA; SILVA, 2016). A esses dois aspectos, pode-se acrescentar ainda a condição dinâmica do objeto arquitetônico, que chega aos dias atuais como resultado de uma série de agenciamentos provenientes de diversas épocas, cujo reconhecimento solicita metodologias e sistemáticas para coleta, organização e análise de dados.

A origem dos inventários remonta ao século XV, mais precisamente por volta do ano de 1420, momento no qual Choay (2006) situa o nascimento do monumento histórico. Desde então, “[...] o desenho configura-se em uma das formas mais importantes de registro da arquitetura, ao possibilitar relações precisas entre a sua materialidade e a virtualidade da representação [...]" (FREITAS; TIRELLO, 2010, p. 3). Atualmente, tal registro dispõe de inúmeras possibilidades de instrumentos e recursos tecnológicos que dão suporte desde a etapa do levantamento cadastral até a gestão de bancos de dados complexos. Mas ainda é comum que haja certa desconfiança no campo da Preservação Arquitetônica com relação ao emprego de suportes digitais dado seu não raro direcionamento para a produção de simulacros desvinculados da história.

\footnotetext{
0 processo de adequação do ambiente de registro multimídia (tridimensionais) aos critérios conservativos e orientações especializadas - fundamentadas em estudos documentais preliminares - devem formatar novas vertentes informativas, levando em conta não só os conteúdos tecnológicos, mas também, os historiográficos (TIRELLO, 2006, p. 3).
}

Por outro lado, no Brasil, destacam-se as experiências positivas de documentação arquitetônica nas quais foram empregadas interfaces digitais, conjugadas ao conteúdo historiográfico, transcorridas na Casa de Dona Yayá e na Vila Penteado, no âmbito do projeto Arqueometria e Restauração: Sistemas de Documentação para Registro e Leitura Estratigráfica de Edifícios Históricos, coordenado pela Prof ${ }^{\mathrm{a}}$. Dr ${ }^{\mathrm{a}}$. Regina Andrade Tirello, no Programa de Conservação e Restauração de Bens Arquitetônicos e Integrados do CPC-USP. Tais estudos tinham como premissa o reconhecimento das cronologias construtivas dos edifícios em questão, que não dispunham de fontes documentais tradicionais, apenas da matéria arquitetônica como fonte informativa. Tais experiências inserem-se no rol das premissas da Arqueologia da Arquitetura, cuja conformação enquanto campo disciplinar se iniciou na Itália, nos anos de 1970, e, no Brasil, na década de 1990.

Em Arqueologia da Arquitetura, “[...] cada edifício histórico existente, na realidade, não se refere a apenas um, mas a dois, três, dez ... ou quantas vidas tenham nele passado que ainda estão presentes em sua estrutura física atual [...]” (BOATO, 2008, p. 18, tradução nossa). Tal perspectiva põe em discussão a própria produção historiográfica baseada em estilos, que situam a edificação em um dado período histórico como objeto inerte. 
[...] o entendimento dos edifícios como estruturas estratificadas amplia sobremaneira as possibilidades de estudo das construções para muito além dos costumeiros (e por vezes restritivos) estudos de repertório estilístico e tipológico para explicar mudanças formais e temporais. Os edifícios são produtos da cultura humana e, por isso, consideradas obras dinâmicas, constantemente abertas a novas alterações, ou seja, não se relacionam a apenas um período histórico, ou a determinado estado original (VILLELA, 2015, p. 247).

E sendo a cidade moldada pela arquitetura, a paisagem urbana também é resultado de diversos tempos que se sobrepõem. O espaço, de acordo com Milton Santos (2006), é um produto em constante transformação, permeada de rugosidades.

Chamemos rugosidade ao que fica do passado como forma, espaço construído, paisagem, o que resta do processo de supressão, acumulação, superposição, com que as coisas se substituem e acumulam em todos os lugares. As rugosidades se apresentam como formas isoladas ou como arranjos (SANTOS, 2006, p. 92).

Tais rugosidades se aproximam daquilo que em Arqueologia é identificado como como estrato. "Os estratos atestam situações em que existe um processo contínuo de formação da matéria, que vai do momento de sua criação à contemporaneidade [...]" (VILLELA, 2015, p. 54). É um termo derivado da Geologia, amplamente difundido entre arqueólogos, e que em Arqueologia da Arquitetura vem sendo empregado para identificar as transformações sucedidas no objeto arquitetônico e na paisagem urbana.

Desvelar camadas de tempos e imaginar dinâmicas, lógicas antrópicas de enraizamento e de mobilidade na paisagem significa imaginar fluxos em caminhos e rios nas suas possibilidades e dificuldades de comunicação, em busca dos vestígios de uma fenomenologia dos modos de ser e estar em escala macrorregional. (BUENO, 2017, p. 243).

Elevar a matéria como protagonista dos estudos arquitetônicos e urbanos significa superar o entendimento do patrimônio cultural como um conjunto de edificações monumentais, em geral, relacionados às classes detentoras do poder. Significa ainda superar a predileção pelo estudo da "arquitetura oficial", produzida por escritórios de profissionais diplomados, e por aquelas atreladas aos grandes fatos nacionais, noção essa derivada do Decreto-lei 25 de 1937. Raramente são objeto de inventários, tombamentos ou pesquisas históricas as "arquiteturas menores", aquelas produzidas por artífices, mestres-de-obras, pedreiros e práticos-licenciados. A ausência parcial ou total de documentos é um dos limitadores na condução desses estudos. Mas tais lacunas informativas poderiam ser supridas se oferecido um repertório instrumental e metodológico para o estudo direto das edificações, considerando o potencial documental da matéria arquitetônica, que é, inclusive, o que distingue o objeto arquitetônico dos demais objetos historiográficos.

A distinção fundamental entre o objeto de estudo da historiografia geral e das historiografias da arte e da arquitetura se refere ao tipo de temporalidade de ambos: [...] para a historiografia geral o objeto não existe mais no tempo, e o primeiro trabalho do historiador é o de fazê-lo reviver, por assim dizer, o de trazê-lo para o presente mediante sua descrição ou sua narração. Enquanto o objeto das historiografias da arte e da arquitetura existe no presente por si mesmo, e o trabalho do historiador deve partir desta realidade presente. No primeiro caso, o protagonista é um acontecimento, um personagem ou uma cultura que teve lugar no tempo e desapareceu [...] No segundo, o protagonista - a obra de arte ou arquitetura - apesar de pertencer a outro tempo e lugar, é em si mesma o testemunho histórico principal e imprescindível, o que reúne em si os dados mais significativos para seu conhecimento. (WAISMAN, 1993, p. 18, tradução nossa). 
Movidos por essas questões, apresenta-se neste artigo uma reflexão crítica acerca das experiências realizadas no âmbito da disciplina IAU5818 - Tecnologias Digitais na Documentação do Patrimônio Arquitetônico, oferecida pelo Programa de Pós-Graduação do IAU-USP em maio de 2018, desenvolvida a partir de um exercício experimental de observação, organização e representação de dados obtidos por meio de Fotogrametria. Como objeto de estudo, selecionou-se o perfil construído no entorno da Praça XV de Novembro ${ }^{1}$ e da Praça Carlos Gomes, localizadas no Quadrilátero Central de Ribeirão Preto (SP) - área delimitada pelas avenidas Francisco Junqueira, Independência, Nove de Julho e Jerônimo Gonçalves. Trata-se do conjunto urbano que corresponde ao local de fundação da cidade, intensamente modificado desde então, cujo processo de formação e transformação é desconhecido.

O Arquivo Público e Histórico de Ribeirão Preto (APHRP) dispõe de alguns documentos fotográficos, cartográficos e textuais, mas que, individualmente, são insuficientes à compreensão de seu processo de formação e transformação, pois além de capturar fragmentos da área, têm grandes lacunas temporais. A aproximação deste trabalho com a Arqueologia da Arquitetura se apresenta justamente como uma possibilidade de compreensão da dinâmica espaço-tempo dentro do recorte territorial de estudo, a partir do confrontamento de documentos existentes (mapas e fotografias) com documentos produzidos (ortofotos e mosaicos fotográficos). Não se pretende encerrar discussões acerca do uso de tecnologias digitais na documentação de edifícios históricos, mas sim apresentar uma proposta metodológica desenvolvida em campo, que além da fotogrametria enquanto meio de registro, constituiu-se em importante exercício de observação e leitura da paisagem urbana.

\section{O PERFIL CONSTRUÍDO DO ENTORNO DAS PRAÇAS XV DE NOVEMBRO E CARLOS GOMES}

Na atual Praça XV de Novembro de Ribeirão Preto, em 19 de junho de 1856, fundou-se o "patrimônio de São Sebastião”, fruto da doação de terras de fazendeiros da região, iniciada em 1852. O patrimônio religioso era constituído de terras rurais concedidas à Igreja Católica para formação de povoados, cujos limites e direitos a ela eram assegurados, ainda que tais povoados fossem elevados à categoria de cidade (GHIRARDELLO, 2010). Na então Província de São Paulo foram vários os patrimônios religiosos formados devido à expansão da lavoura do café. No caso de Ribeirão Preto, a demarcação das terras do patrimônio aconteceu em 1863, mas Lages (2016) defende a hipótese de que a formação de Ribeirão Preto tenha sido espontânea, com base em registros do Arraial de São Sebastião datados de 1857 (LAGES, 2016). Antes de despontar a economia cafeeira, a população já se dedicava ao trabalho nas fazendas e às atividades religiosas, realizadas em uma capela provisória construída de pau-a-pique e coberta de palha nas proximidades da área que em 1862 seria delimitada como Largo da Matriz (FARIA, 2003; LAGES, 2016).

Em 1863, foi escolhido o local da matriz, “[...] toda construída em adobe, com tijolos assentados com argamassa de barro. Toda sua estrutura de travamento, apoios, colunas e amarrações de vigas e pilares eram de madeira aparente. O forro [...] e o assoalho também eram de madeira [...]" (GUIÃO, 1922², p. 11 apud LAGES, 2016, p. 33). Sua localização condicionou os arruamentos e a ocupação do entorno, constituído de casas “[...] de má construção, de grandes beirais, na maioria de pau-a-pique, apenas rebocadas e caiadas [...]” (DOS SANTOS, $1948^{3}$ apud FARIA, 2003, p. 70).

$\mathrm{O}$ aspecto rural da vila, a partir de 1870, começou a mudar devido às atividades comerciais, serviços e lazer, ao enriquecimento impulsionado pelo cultivo do café e à chegada do trem em 1883 (FARIA, 2003; LAGES, 2016).

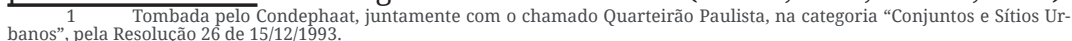
banos", pela Resolução 26 de 15/12/1993.

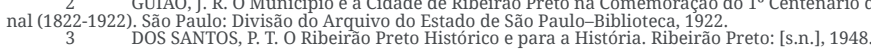


Muitos casebres foram substituídos por construções com platibandas e ornamentos neoclássicos e muitas fachadas reformadas para se adequar ao gosto eclético e aos recentes códigos de posturas. Em 1890, o próprio Largo da Matriz foi redefinido para a construção da Praça Rio Branco, onde em 1917 seria erguido o Palácio Rio Branco, sede da municipalidade. Em 1905, a matriz foi demolida uma nova foi erguida em outra localidade. No lugar da primeira foi construído o Bar Antarctica, mais tarde substituído por uma fonte luminosa, hoje inativa (LAGES, 2016).

O prestígio social e econômico representado por essa área foi chancelado, em 1930, pela inauguração do conjunto arquitetônico formado pelo Teatro Pedro II, Edifício Meira Júnior e Palace Hotel, denominado Quarteirão Paulista, patrocinado pela Cia. Cervejaria Paulista. A importância da praça “[...] no contexto urbano de Ribeirão Preto está também revelada no discurso visual de um conjunto de fotografias, impressas ou não, que evidenciam, pelo olhar do fotógrafo, a própria modernidade urbana [...]" (FARIA, 2006, p. 41). Embora tais fotografias evidenciem as sucessivas intervenções arquitetônicas e urbanísticas nela empreendidas, não existem estudos que datem de forma sistemática as mudanças decorridas na área central de Ribeirão Preto.

Compreender o processo de formação e transformação, seus agentes (públicos e privados) e fatores (sociais, políticos e econômicos), inclusive para que se possam estabelecer medidas eficazes de proteção às edificações de interesse histórico remanescentes, requer, primeiramente, o levantamento das formas urbanas e arquitetônicas. Tais levantamentos vem sendo viabilizados por meio do emprego de tecnologias digitais, tais como a Fotogrametria terrestre, o 3D Laser Scanning e o Historical Geographic Information System (HGIS), cuja aplicabilidade varia de acordo com os propósitos da documentação e, de maneira alguma, substituem as fontes informativas indiretas. Por isso, foram delimitadas três categorias de fontes - construções sem documentação (a matéria arquitetônica é a única fonte informativa), construções com documentação (edifícios existentes que dispõem de fotos, desenhos e mapas) e documentação sem construções (fotos, desenhos e mapas de edifícios demolidos) - e desenvolvida a metodologia ilustrada na Figura 1.
Figura 1: Metodologia de documentação do objeto de estudo

Fonte: Elaborado pelos autores.

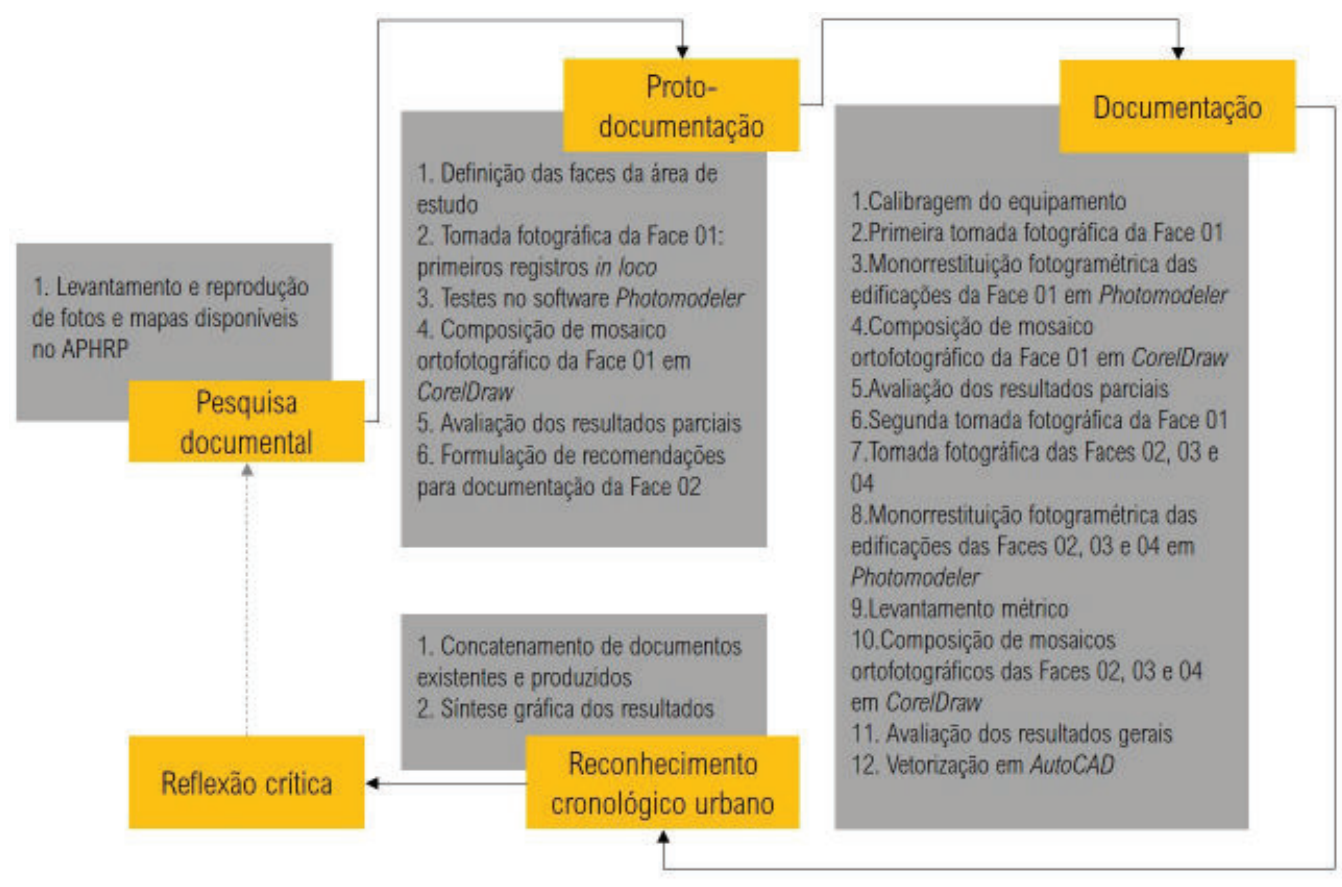


A área de estudo foi dividida em quatro faces sendo elas: Face 1: Rua General Osório; Face 2: Rua Barão do Amazonas; Face 3: Rua Duque de Caxias; e Face 4: Álvares Cabral (Figura 2).
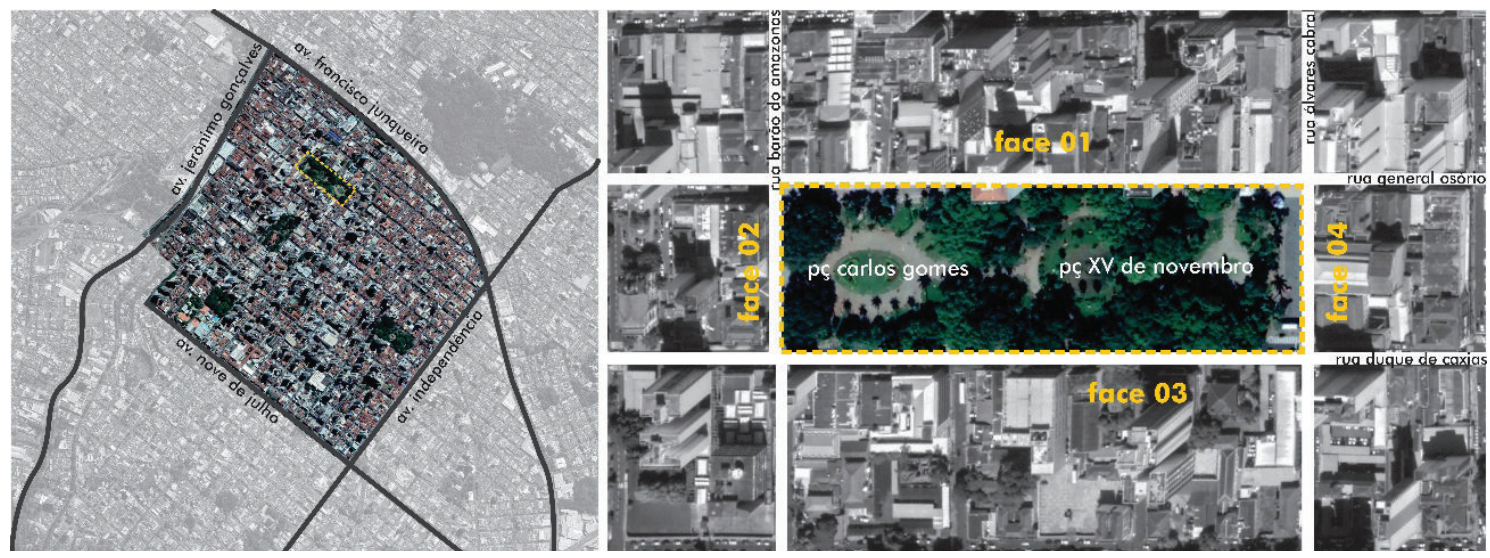

Figura 2: Quadrilátero Central de Ribeirão Preto e localização da Praça Carlos Gomes e da Praça XV de Novembro

Fonte: mapas do Google Earth com intervenção dos autores.
A primeira face foi escolhida por, aparentemente, apresentar menos obstáculos às tomadas fotográficas (tais como fiações elétricas aparentes e árvores) entre a câmera e os edifícios. Ainda assim, foi desenvolvida uma etapa de teste, chamada de proto-documentação ${ }^{4}$, para mapear erros, avaliar a qualidade das fotos e das restituições fotogramétricas e, eventualmente, reajustar os procedimentos adotados. Foi usada uma câmera Canon EOS Rebel T5i, objetiva $18 \mathrm{~mm}$, devidamente calibrada, e as restituições fotogramétricas feitas no software Photomodeler Scanner. A princípio, não foi utilizado tripé e, além da baixa altura da câmera, não havia estabilidade. O uso do tripé, que elevou a câmera cerca de $2 \mathrm{~m}$ do chão, permitiu melhor alinhamento horizontal e vertical do plano fotografado. Além disso, foi escolhido outro horário para produção das fotos, uma vez que o fluxo de pessoas entre a câmera e o edifício, acabou encobrindo partes da primeira sessão de fotos (Figura 3).
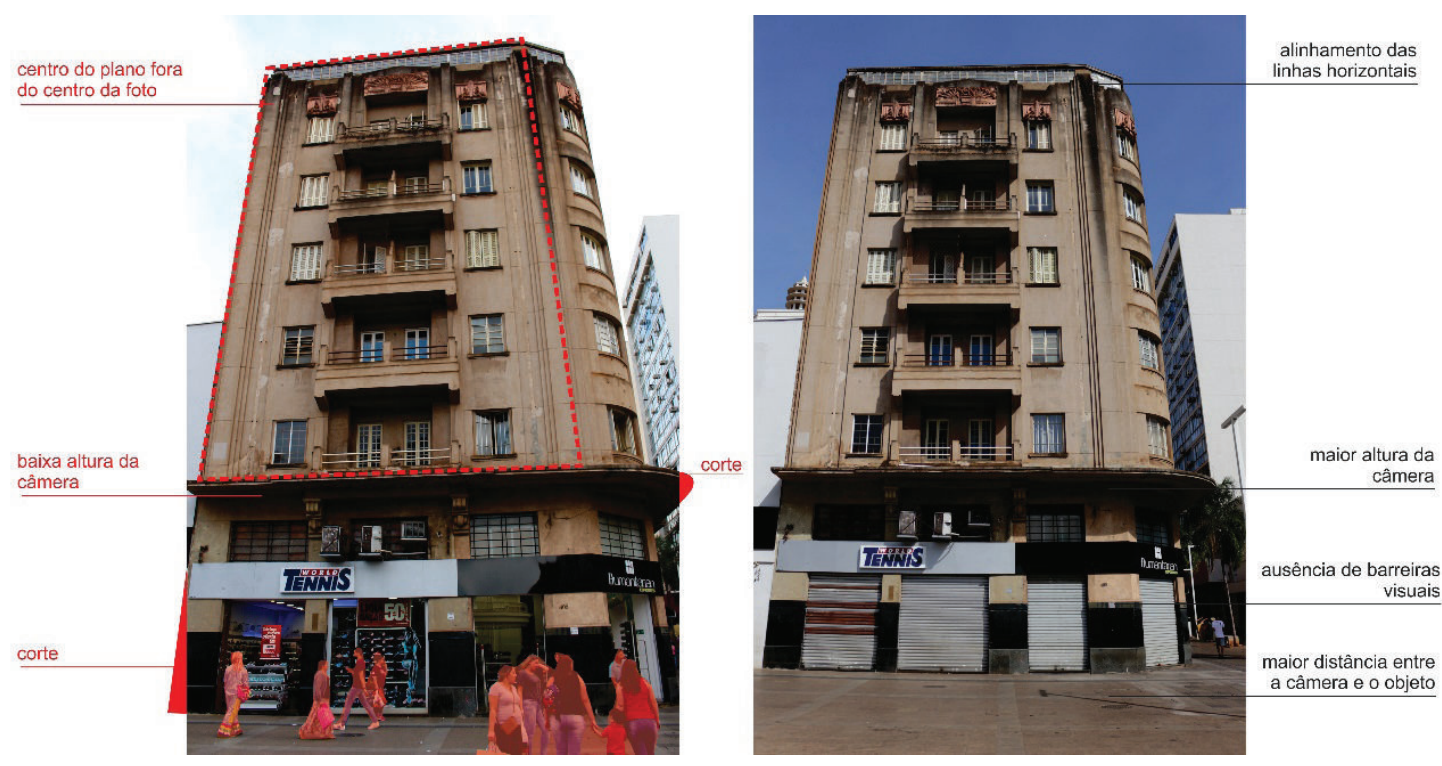

Figura 3: Comparativo entre uma foto capturada sem tripé (foto de 1 jun. 2018), durante a etapa da proto-documentação, e outra com tripé, durante a etapa de documentação (foto de 16 jun. 2018).

Fonte: Elaborado pelos autores.

4 Etapa de teste que antecedeu a documentação fotográfica das 4 faces de estudo, a partir da qual foram identificados os erros a serem sanados (ou minimizados). 
Havia três caminhos metodológicos possíveis: a "monorrestituição" , a "restituição a partir de várias fotos" e o "Dense Stereo Matching" $(\mathrm{DSM})^{6}$. Muito embora a técnica de restituição a partir de várias fotos seja considerada pelos especialistas como a mais adequada para o cadastramento de formas poliédricas (GROETELAARS, 2015, p. 72), os resultados obtidos com o jogo de uma foto ortogonal e duas fotos oblíquas $\left(45^{\circ}\right)$ na etapa da proto-documentação não foram satisfatórios. Alguns edifícios eram muito altos ou muito compridos e parcialmente encobertos por árvores, o que gerou uma série de erros durante o processo de restituição das imagens pelo software. Para o caso específico de estudo, o método da monorrestituição pareceu mais oportuno já que a maioria das fachadas capturadas tinham poucas variações de profundidade, além de que este processo solicita um menor tempo de processamento das imagens.

No caso de fachadas planas, as deformações foram mínimas, no entanto, a existência de uma marquise ou qualquer volume sobressaltado tornou necessária a decomposição das fachadas em várias fotos para reduzir tais deformações, não sendo possível elimina-las por completo. Na Figura 4, são apresentados em diagramas os erros mapeados ao longo das tentativas de tomadas fotográficas do Hotel Metrópole, um edifício cujo volume superior se projeta à frente do piso térreo e com uma das quinas abaulada. Em vermelho, destacam-se os trechos com alto grau de distorção das fotos, que foram minimizados com a decomposição do edifício em várias partes. A saber: volume superior (1), sobreloja (2), térreo (3) e esquina (4).
Figura 4: Mapeamento de erros do Hotel Metrópole (Face 1)

Fonte: Elaborado pelos autores.
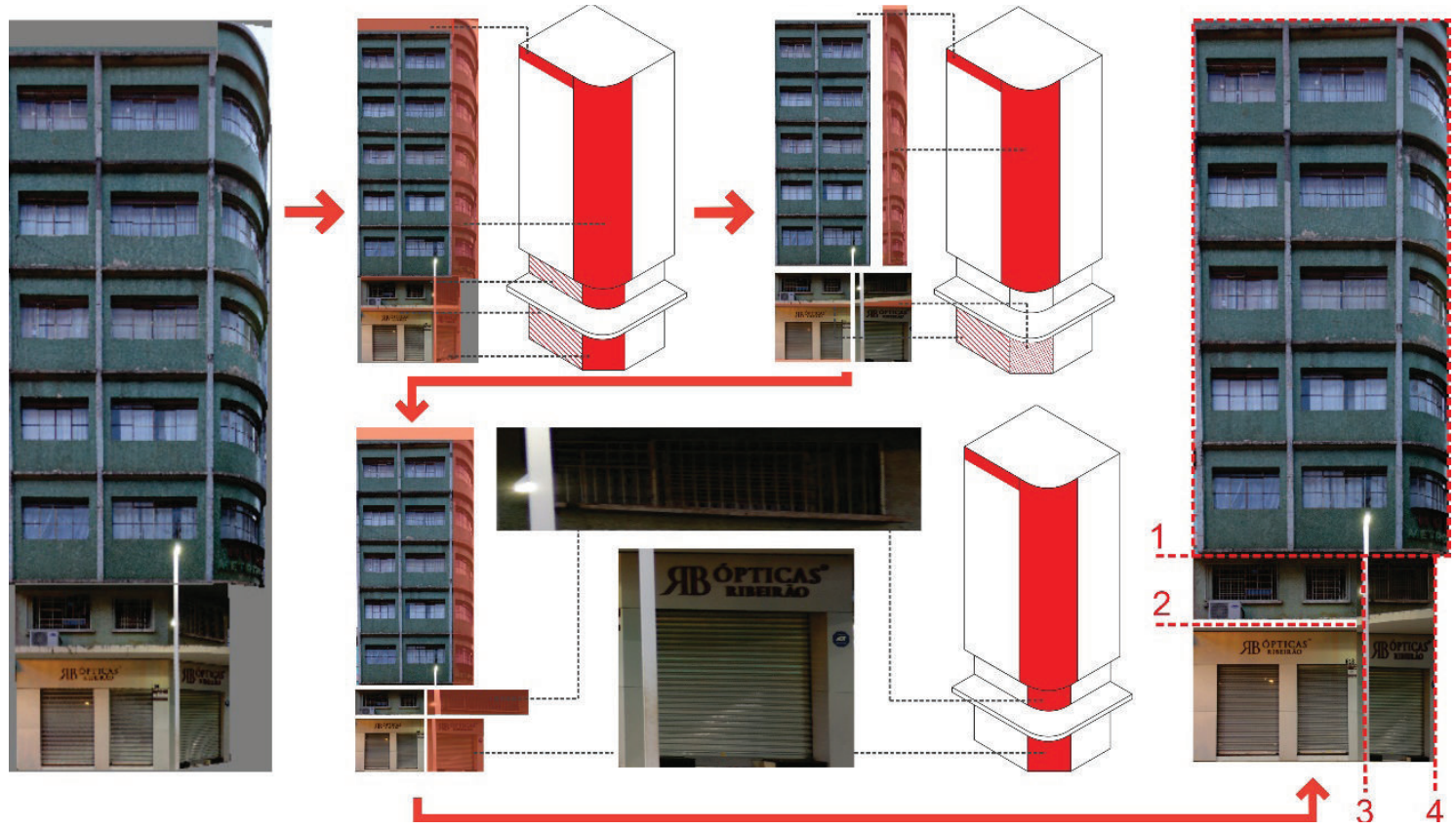

\section{DA PROTO-DOCUMENTAÇÃO À DOCUMENTAÇÃO DA FACE 1}

Minimizadososproblemasidentificadosna etapa deproto-documentação, deu-se início à segunda tomada fotográfica da Face 1, esta sim bem-sucedida. Assim que concluída, foram levantadas as dimensões horizontais de todas as frentes de lote de modo que as ortofotos a serem produzidas no Photomodeler Scanner estivessem com as medidas reais. As ortofotos foram então exportadas em formato “.jpg” na escala 1:100 e com resolução de 300 dpi. As fachadas com diversos planos e aquelas com comprimento acima de $15 \mathrm{~m}$ foram desmembradas e, ao invés de uma ortofoto para o edifício, foram feitas várias ortofotos, cada uma correspondendo a um trecho da

Consiste na restituição dos objetos, no caso, as fachadas, a partir de uma única foto.
6 "O funcionamento da técnica DSM baseia-se na correlação automática de conjuntos de $p$

6 "O funcionamento da técnica DSM baseia-se na correlação automática de conjuntos de pixels homólogos em diferente ELAARS, 2015, p. 72). 
edificação. Finalizadas as ortofotos, foram elaborados os mosaicos (Figura 5) em Corel Draw 2017. Estes foram exportados em formato “.jpg” e inseridos (attach) como imagens raster no AutoCAD para vetorização das fachadas. Durante o processo de vetorização, as deformações perspécticas tornaram-se novamente um complicador no caso de fachadas com vários planos. Tais deformações foram corrigidas durante o processo de vetorização por meio do uso de fotografias parciais, que continham os pormenores a serem desenhados.

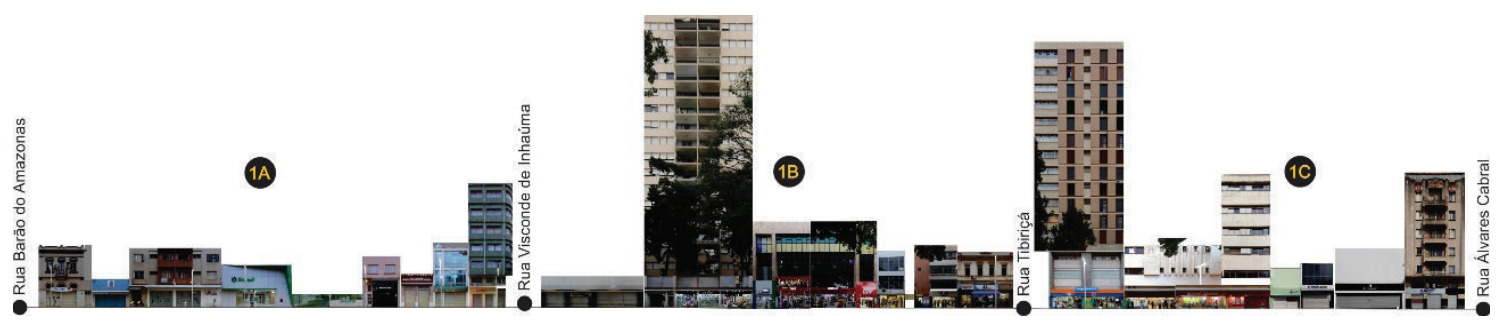

Figura 5: Mosaico fotográfico da Face 1, referente à Rua General Osório, entre as Ruas Álvares Cabral e Barão do Amazonas.

Fonte: Elaborado pelos autores.

Nos primeiros registros do Largo da Matriz (Figura 6), nos quais se vê ao fundo a Rua General Osório, predominam na paisagem casas térreas, com fachadas de um único plano e alinhadas às calçadas, características essas derivadas das exigências do primeiro código de posturas de 1889 (FARIA, 2003). Aos poucos os beirais projetados sobre as calçadas foram sendo substituídos pelas platibandas, como se pode observar nas fotos aqui reproduzidas, mas ainda não havia nenhum tipo de exigência estética, o que só apareceria no Código de Posturas de 1921 (FARIA, 2003).
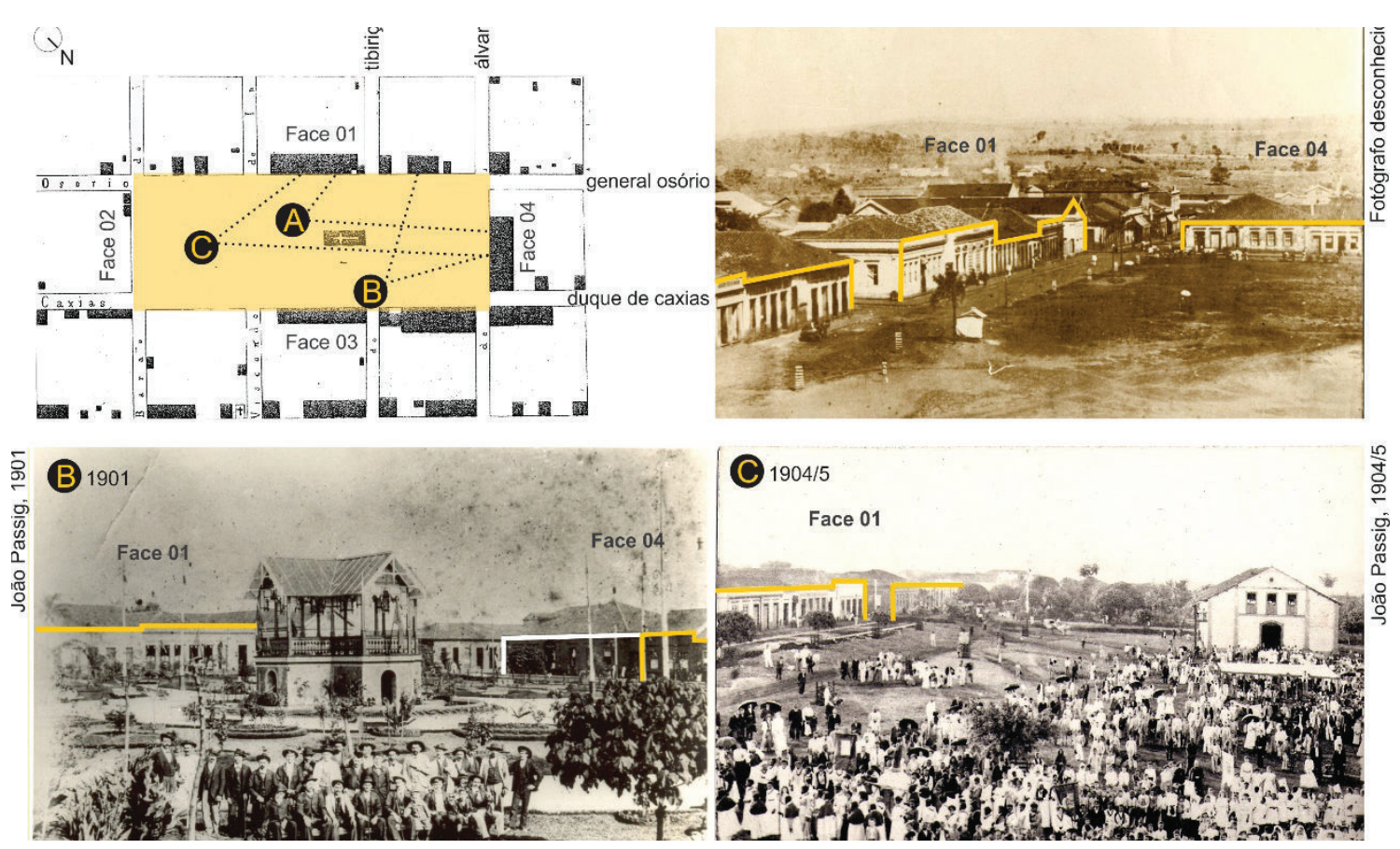

Figura 6: Trecho do mapa da Vila de Ribeirão Preto, de 1874, com os quarteirões em volta do Largo da Matriz com indicação dos pontos das tomadas fotográficas das imagens A, B e C. Em amarelo, edificações construídas até 1874 e, em branco, posteriores a essa data

Fonte: APHRP com intervenção dos autores. 
Por interligar o Largo da Matriz à estação ferroviária da Cia. Mogyana, a rua se configurou como o principal eixo comercial da vila, definindo como tipologias arquitetônicas edificações térreas de uso exclusivo comercial e sobrados com térreo comercial e piso superior residencial. O perfil primitivo da rua foi completamente modificado entre as décadas de 1910 e 1920, quando a arquitetura assumiu o vocabulário eclético (Figura 7).

O ecletismo foi, segundo Lemos (1989), o momento do desregramento, da imaginação e da recriação. Mais do que uma questão estética, havia também nas obras ecléticas uma ampliação do repertório técnico e material, influenciado sobretudo pelo imigrante recém-chegado. As casas de taipa, remanescentes das "velhas" cidades paulistas foram sendo gradativamente substituídas "[...] por novos partidos ligados a uma nova sociedade, dona de outros hábitos, usos e costumes mesclados e de modernos critérios seletivos mercê de novos conhecimentos, novos códigos, novas leis [...]” (LEMOS, 1989, p. 35).

A arquitetura eclética não se limitou à decoração de fachadas. Ela introduziu o uso de novos materiais, muitos importados, às construções brasileiras, e impulsionou a qualificação da mão-de-obra, por meio da criação das primeiras escolas de artes e ofícios, uma delas, inclusive, em Ribeirão Preto. Mas poucos são os exemplares remanescentes desse período na área de estudo, como se pode observar comparativamente nas Figuras 4, 5 e 6. Houve um rompimento abrupto no perfil edificado defronte à Praça $\mathrm{XV}$ de Novembro, tanto em termos de linguagem arquitetônica como de gabarito. Esse processo de modificação da paisagem teve início ao final da década de 1930, mais precisamente em 1936, quando foi inaugurado um dos principais marcos da "moderna" Ribeirão Preto, o Edifício Diederichsen. Modernidade que se traduziria pela estética do Art Decó. Esse edifício foi o primeiro a romper com o gabarito predominante na Rua General Osório, além de introduzir uma nova tipologia arquitetônica de usos mistos.

O momento econômico e político nacional no qual se insere a construção do Diederichsen foi caracterizado pela "[...] queda das oligarquias agro-exportadoras, a ascensão em 1930 de um governo nacionalista (Getúlio Vargas) e sua retórica modernizadora, o início da industrialização, o surgimento do proletariado e a consolidação das classes médias urbanas [...]" (BLANCO; CAMPOS NETO, 2003), fatores que ensejaram novas levas de renovações urbanas. Nesse período houve um impulso de verticalização dos centros urbanos, que em Ribeirão Preto se iniciou na Praça XV, propiciado pela disseminação do uso do concreto armado.

Na foto aérea da década de 1950 (Figura 8), além do Diederichsen, defronte à Praça Carlos Gomes, é possível ver a estrutura do Hotel Metrópole sendo erguida. Edificações de usos mistos, como o Edifício Abrão Boainain, o Edifício das Palmeiras (na esquina com a Rua Tibiriçá) e o Edifício João F. S. Pupo, remontam aos anos de 1960, década na qual o centro como um todo passa por densas modificações resultantes da transferência da estação ferroviária para a zona nordeste da cidade. No centro intensificou-se o uso do solo pelo comércio popular e atacadista (FIGUEIRA, 2013) e a maioria das antigas edificações do entorno da Praça XV de Novembro e Carlos Gomes foram demolidas ou descaracterizadas.

Uma nova cidade se escrevia sobre aquelas duas anteriores, a colonial e a eclética. 

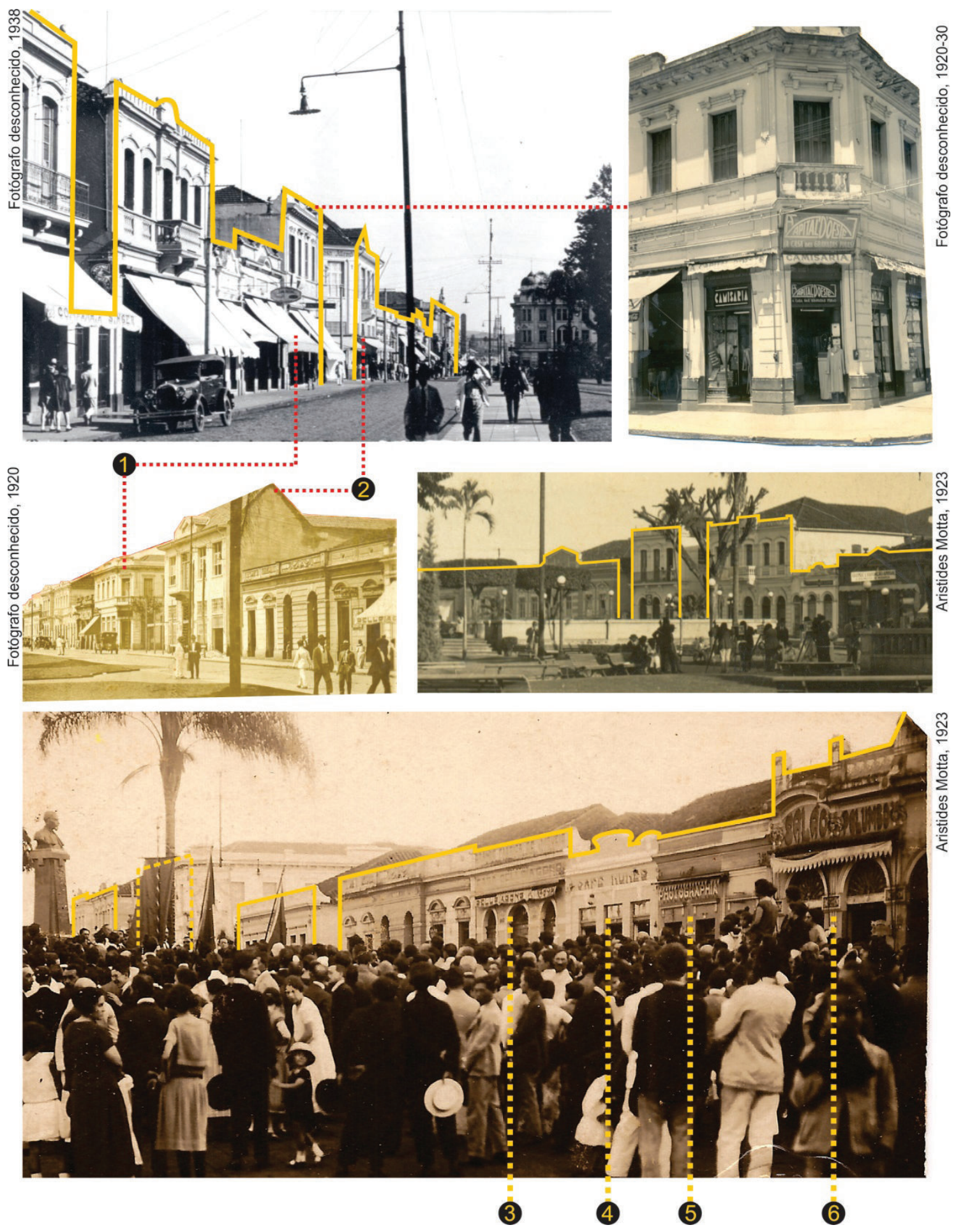

Figura 7: Fotografias tiradas a partir da Praça XV de Novembro, na década de 1920. 1- Capital D'Oeste - a casa das gravatas finas; 2- Casa Alemã; 3- Grande Fábrica de Móveis Deloiagono; 3- Café Nunes; 4- Photographia; 5- Salão Palumbbo.

Fonte: APHRP com intervenção dos autores. 


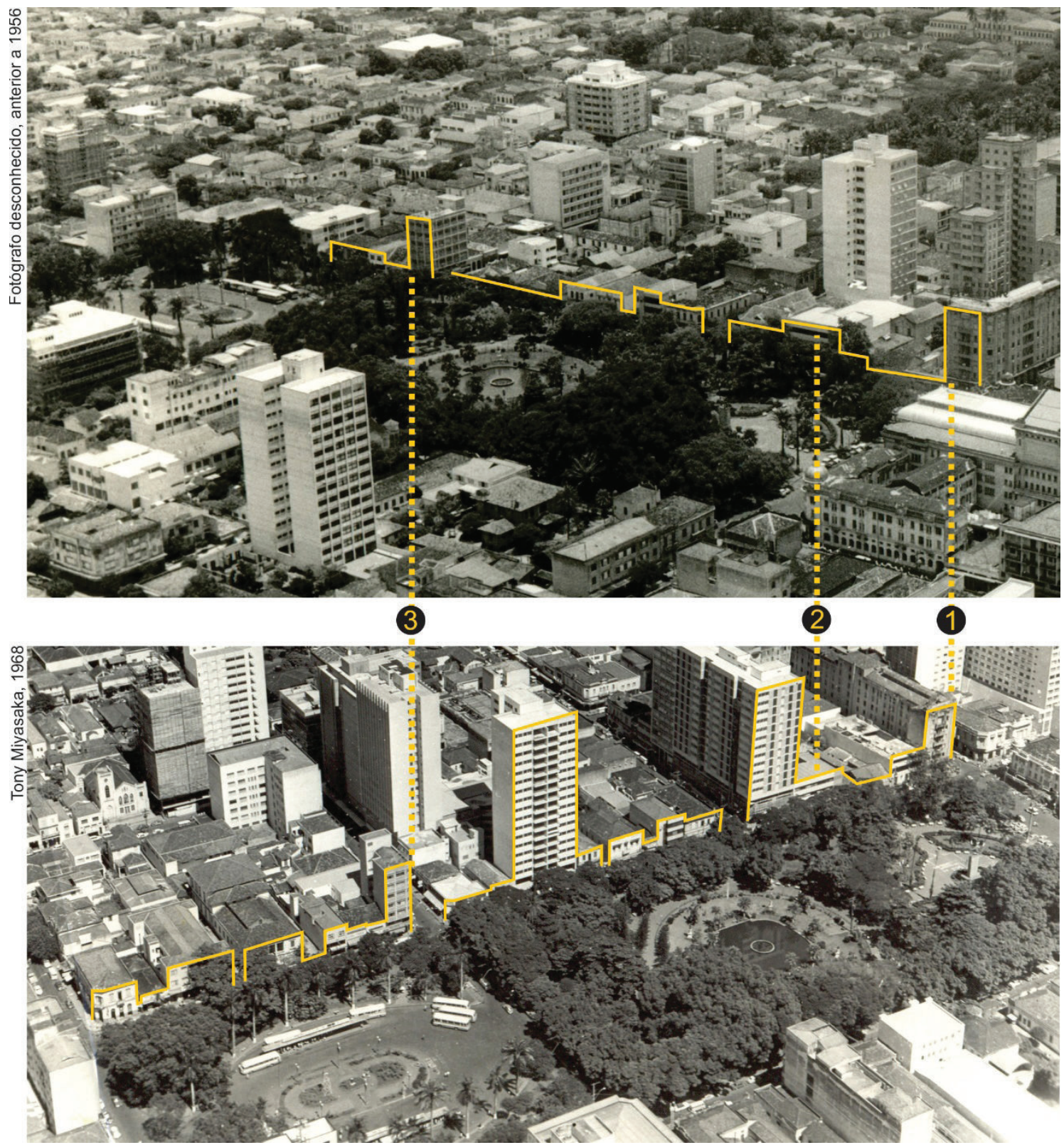

Figura 8: Fotografias aéreas das décadas de 1950 e 1960. 1-Edifício Diederichsen; 2-Edifício Alice Boainain; 3- Hotel Metrópole. Fonte: APHRP com intervenção dos autores.

\section{DOCUMENTAÇÃO DA FACE 2}

O trecho da Rua Barão do Amazonas defronte à Praça Carlos Gomes aparece em pouquíssimas fotos, ao menos dentre aquelas disponibilizadas pelo APHRP. O levantamento fotogramétrico, por sua vez, permite a verificação dos diferentes tempos presentes na face deste quarteirão. Na Figura 9, à esquerda, situa-se a antiga sede da Sociedade Recreativa (atual Museu de Arte de Ribeirão Preto), em estilo eclético na esquina com a Rua Duque de Caxias. Embora seguindo a mesma linguagem, o edifício foi construído em dois momentos, que segundo documentos do APHRP remontam aos anos de 1908 e 1922. Este último, edificado no terreno vizinho, apresenta pilares e guarda-corpos de ferro, material raramente verificado 
nas construções da primeira década do século XX.

Na extremidade oposta, na esquina com a Rua General Osório, um edifício de características modernas rompe o gabarito pré-existente. Esse edifício foi, inclusive, documentado por um importante fotógrafo da cidade, Tony Miyasaka, durante sua construção. No térreo, funcionou 0 Cine Centenário, inaugurado em 1956, quando os pisos superiores de uso residencial ainda estavam sendo finalizados. O cinema foi fechado e hoje funcionam estabelecimentos comerciais. Entre as edificações situadas nas esquinas, há duas edificações bastante descaracterizadas, mas cujas características ornamentais das platibandas aderem à linguagem do Art Decó, com linhas retas e motivos geométricos, provavelmente construídas na década de 1940 .

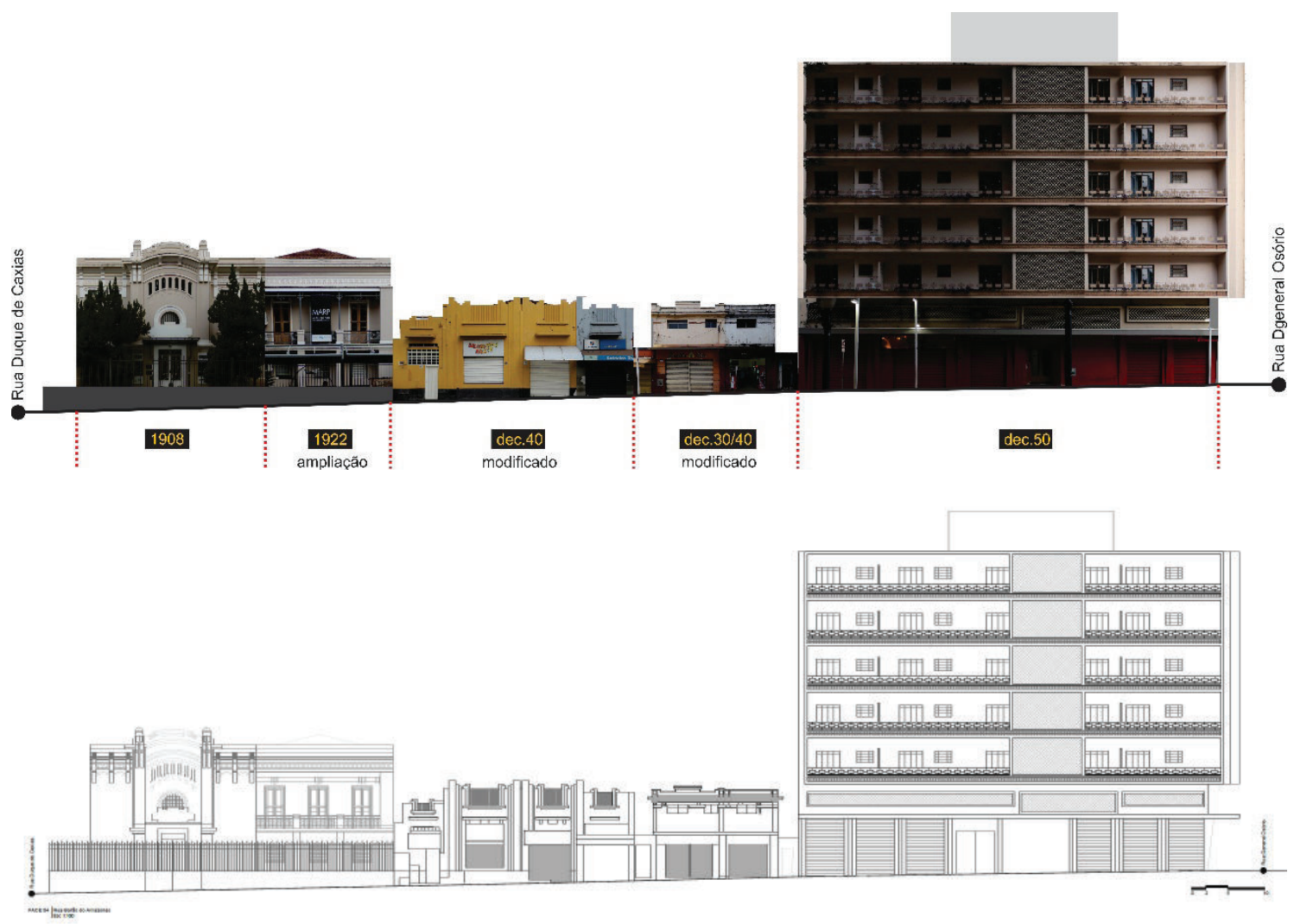

Figura 9: Mosaico fotográfico e Vetorização da Face 2, referente à Rua Barão do Amazonas, entre as Ruas General Osório e Duque de Caxias.

Fonte: Elaborado pelos autores.

\section{DOCUMENTAÇÃO DA FACE 3}

Poucos são os exemplares arquitetônicos históricos remanescentes no trecho levantado da Rua Duque de Caxias. Na década de 1930 (Figura 10), o gabarito era de um ou dois pavimentos e a linguagem do ecletismo definia as fachadas das edificações ali erguidas, algumas que, inclusive, "escondiam" casebres do final do século XIX, adequadas ao código de posturas de 1902. Apesar de poucos remanescentes históricos, este trecho da praça ainda guarda dois exemplares de uma nova tipologia arquitetônica que ascenderia a partir da década de 1920, os palacetes de influência neocolonial que serviram de residência à Sinhá Junqueira e a Camilo de Matos. O palacete já era uma tipologia difundida na capital paulista desde o início da Primeira 
República, “[...] quando surgia uma nova São Paulo, construída de alvenaria de tijolos, e os capitais provinham da lavora do café [...]” (HOMEM, 2010, p. 13). Em Ribeirão Preto, no entanto, os palacetes começaram a aparecer na paisagem urbana mais tardiamente e, ao invés de aderentes ao gosto eclético, assumiram o caráter neocolonial. No Código de Posturas de 1889, havia a exigência de que nenhum edifício seria levantado fora da linha do arruamento, e, quando o fosse, deveria ser fechado por muros ou gradis” (Art. 4 do Código de Posturas da Câmara Municipal do Ribeirão Preto apud. FARIA, 2003).
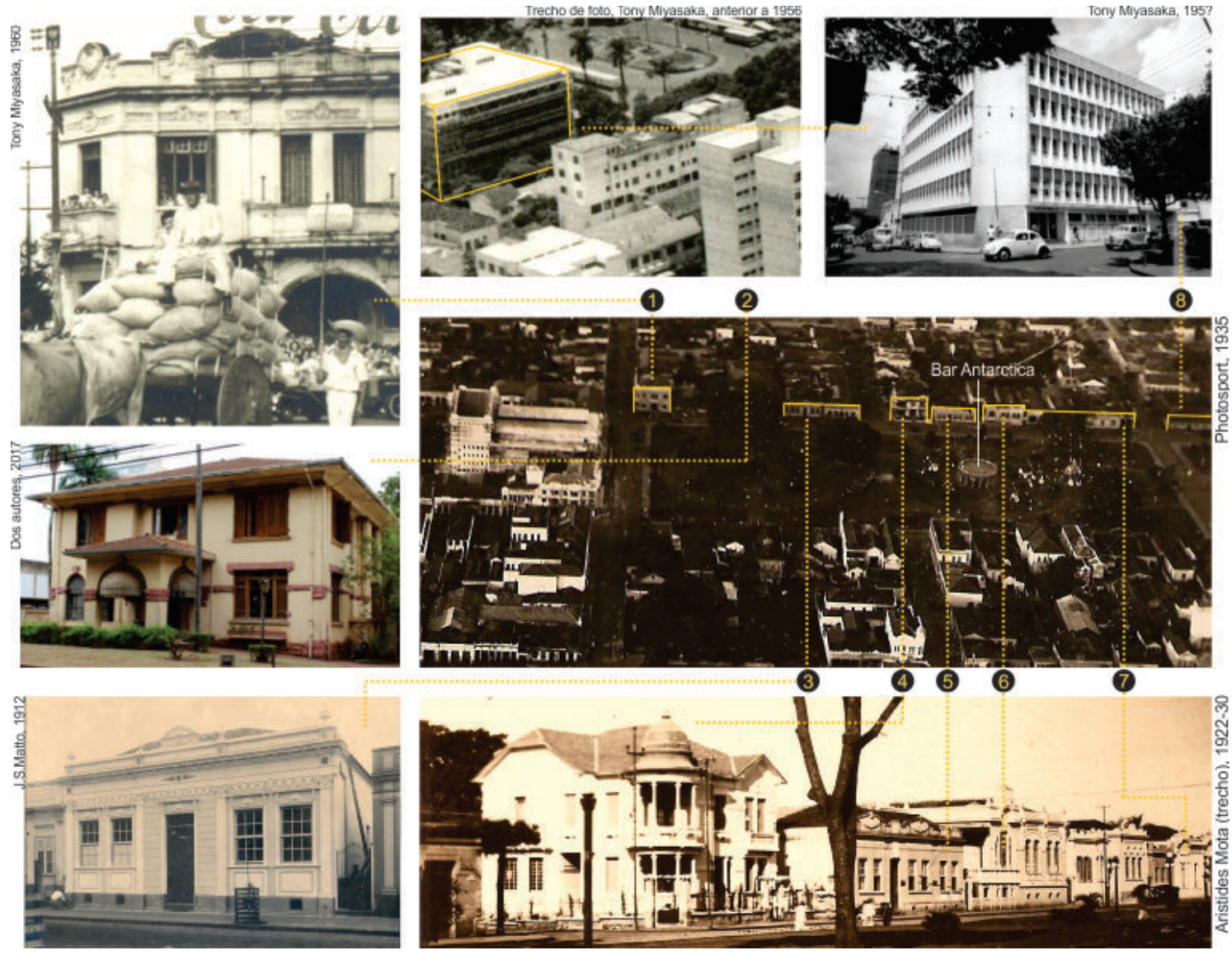

Figura 10: Fotografias das edificações existentes e demolidas da Face 3 (Rua Duque de Caxias). 1-Sobrado (demolido - atual Banco Safra): 2-Residência Sinhá Junqueira (atual Biblioteca Altino Arantes); 3-primeira residência de Coronel Francisco Maximiano Junqueira (demolida); 4-Palacete Camilo de Matos; 5-6-casas térreas (demolidas); 7-casa térrea (corpo da casa demolido; fachada original remanescente); 8-casa térrea (demolida-atual Banco do Brasil).

Fonte: APHRP, com intervenção dos autores.

Em contraste com os palacetes, as edificações mais recentes apresentam geometrias bem mais simplificadas. Apesar disso, a elaboração das ortofotos foi muito trabalhosa devido às grandes extensões horizontais e ao encobrimento de seu topo pelas copas das árvores, de modo que a minimização dos erros só foi possível durante o processo de vetorização. 


\section{DOCUMENTAÇÃO DA FACE 4}

A face da Rua Álvares Cabral que se volta para a Praça XV de Novembro corresponde ao mais famoso trecho urbano de Ribeirão Preto, o Quarteirão Paulista (Figura 11). Este conjunto é resultado da iniciativa da Companhia Cervejaria Paulista que patrocinou a construção de dois edifícios, o Teatro Pedro II e o Edifício Meira Junior (atual Choperia Pinguim) e a reforma do Central Hotel (posteriormente, Palace Hotel).

Os terrenos e o hotel eram de propriedade do comerciante de café Adalberto de Oliveira Roxo (SUNEGA, 2011). Curioso é que raros são os registros desta face anteriores à construção do Quarteirão Paulista. Dentre eles, localizou-se a foto do primeiro hotel ali existente, o Hotel Central, uma edificação térrea com implantação em "U”, que foi demolido posteriormente para ceder lugar ao teatro. Provavelmente tornou-se obsoleto e, em 1926, Adalberto mandou erguer um novo hotel, o Central Hotel (com a grafia inversa) nos lotes ao lado, estendendo-se até a esquina com a Rua Duque de Caxias. No entanto, quando vendidos os imóveis para a Companhia Cervejaria Paulista, o hotel foi reformado e reinaugurado em 1930, junto com o teatro e o edifício comercial.

Foram aplicados diversos elementos decorativos na fachada, como frontões e florões, acompanhando as ornamentações dos demais edifícios que formariam o Quarteirão Paulista. As varandas de esquina foram fechadas, a entrada recebeu um toldo de vidro similar ao do Theatro Pedro II e uma cúpula igual ao do edifício Meira Júnior foi construída. (SUNEGA, 2011, p. 35).

Não cabe reproduzir aqui todo o processo de concepção e construção do conjunto, mas é interessante perceber as diferentes temporalidades escritas sobre o mesmo espaço urbano, cujo perfil colonial seria completamente apagado em favor destes três imponentes edifícios. Apesar do estilo eclético, tal arquitetura já não mais se relacionava à economia cafeeira, devido à crise de 1929, mas à ascendente indústria ribeirão-pretana, sobretudo a cervejeira.

Cabe ainda ressaltar que o teatro é, na verdade, uma reconstrução parcial do objeto arquitetônico original, incendiado em 1980. Seu interior foi inteiramente restaurado dentre 1991 e 1996 . Restauro esse que adere ao pensamento estilístico, relacionado à teoria de Viollet-le-Duc (1814-1879), muito criticado durante o século XX por se apoiar na premissa que "[...] restaurar um edifício não é mantê-lo, repará-lo ou refazê-lo, é restabelecê-lo em um estado que pode não ter existido nunca em um dado momento [...]" (VIOLLET-LE-DUC, 2000, p. 29). No entanto, a condição da arquitetura como parte integrante de um conjunto edificado maior, amplia o valor do monumento isolado em favor de seu contexto, ao qual se acrescenta ainda o interesse turístico dessa área. Há, portanto, certa relativização do conceito de autenticidade na chancela de edifícios como monumentos históricos.

O conceito de autêntico refere-se a ser legítimo, genuíno, tanto em relação a ser uma evidência verdadeira de algo, como a pertencer a uma criação humana autônoma [...] Levando-se esse pensamento para a cidade, constata-se que a verificação da autenticidade se dá a partir de um reconhecimento coletivo, ou seja, intersubjetivo, por meio do qual a sociedade busca sua autenticidade. A sociedade busca a autenticidade baseando-se em um conjunto de regras e valores mutáveis ao longo do tempo. (ZANCHETTI et al., 2008, p. 2-3). 


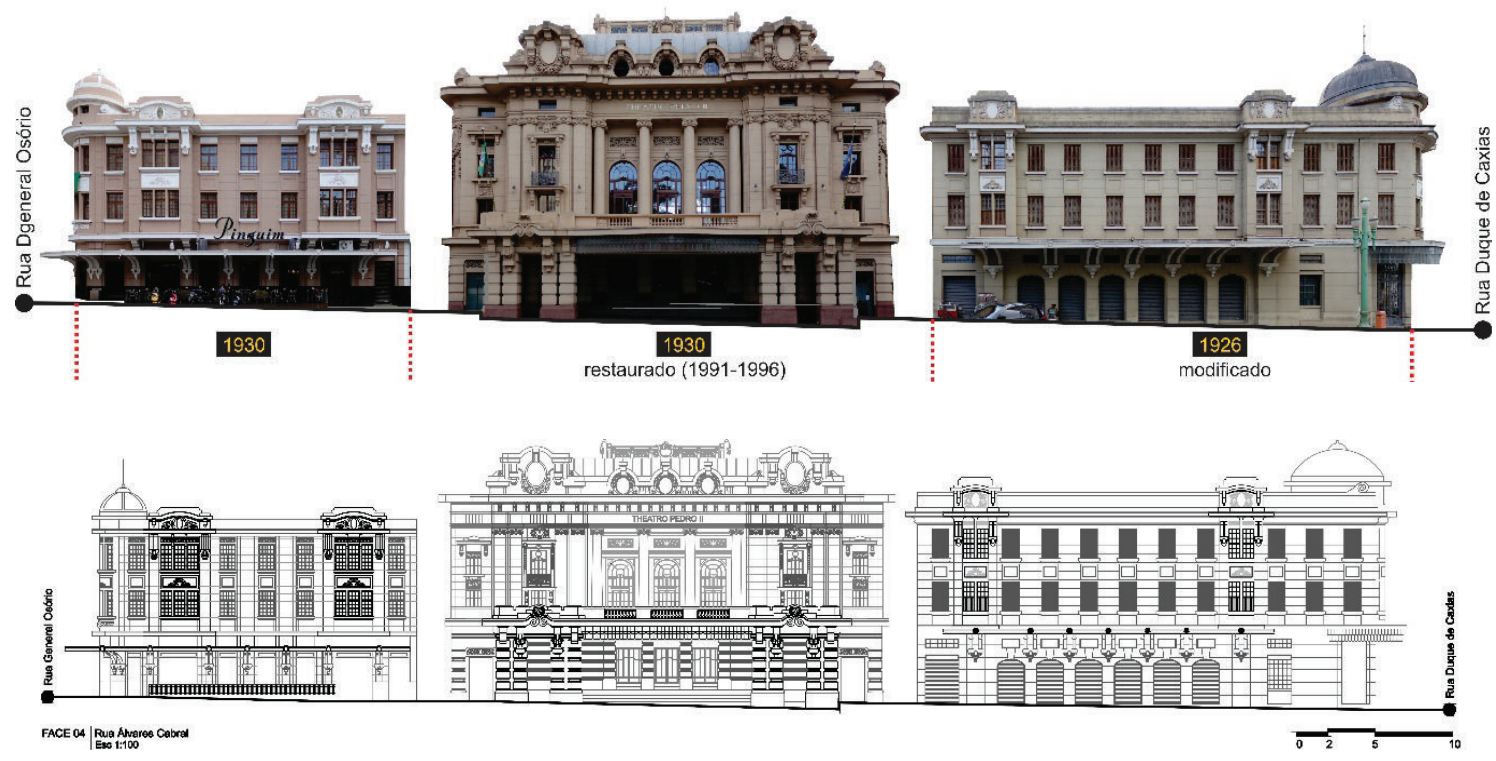

Figura 11: Mosaico fotográfico e vetorização da Face 4, referente à Rua Álvares Cabral (Quarteirão Paulista), entre as Ruas General Osório e Duque de Caxias.

Fonte: Elaborado pelos autores.

Abarcando, pois, não só a revisão do conceito de autenticidade, mas o reconhecimento das "[...] contribuições válidas de todas as épocas para a edificação do monumento [...]” (ICOMOS, 1964, p. 3) retoma-se o argumento inicial de entender a cidade e a arquitetura como objetos heterogêneos, o "palimpsesto urbano" de Pesavento (2004). Para sua leitura, portanto, solicitam-se metodologias de levantamento morfológicos e cronológicos que deem suporte ao reconhecimento dos indícios de tantas transformações decorridas ao longo do tempo sobre a arquitetura e a paisagem que a cerca, superando-se os estudos retrospectivos baseados em estilos inertes.

\section{CONSIDERAÇÕES FINAIS}

A arquitetura e a paisagem urbana são resultados de estratos temporais que se sobrepõem constantemente dado seu caráter dinâmico. Aproximações com a Arqueologia têm ampliado as possibilidades de estudo desses objetos a partir de uma perspectiva material, que vai além das fontes documentais e do restrito repertório estilístico, de modo a explicar mudanças espaciais e temporais. Tais explicações se fazem necessárias a elaboração de projetos de restauração e conservação arquitetônicas, bem como de planos urbanos em áreas históricas. Por se tratar de estudos complexos, nos quais lida-se com muitos dados diretos (materiais) e indiretos (documentais), solicitam bases de anotação gráfica como os mosaicos fotográficos aqui apresentados, produzidos por meio de monorrestituição fotogramétrica.

A fotogrametria terrestre pode ser considerada uma tecnologia viável do ponto de vista financeiro e da facilidade operacional. Para este trabalho foram levantados 40 edifícios: térreos, sobrados e torres com 10 a 20 pavimentos; com fachadas planas e volumes sobrepostos, de idade mais antiga (início do século XX) e outros mais recentes. Como o objetivo do trabalho era oferecer uma base para anotação das temporalidades identificadas na paisagem de estudo - entorno das praças XV de Novembro e Carlos Gomes - adotou-se o recurso da monorrestituição no Photomodeler associado às montagens em Corel Draw. À exceção daqueles com fachadas planas e com comprimentos inferiores a $15 \mathrm{~m}$, nos demais foram detectados problemas relacionados às distorções. Tais distorções foram minimizadas, primeiramente, por meio da 
fragmentação dos planos fotografados, como o exemplo mostrado na Figura 4, e durante o processo de vetorização em AutoCAD.

A fotogrametria de fato é um facilitador dos estudos retrospectivos, seja na escala da arquitetura ou da cidade, mas nem ela nem outra tecnologia empregada dispensam o levantamento documental e o levantamento métrico-arquitetônico in loco, cujos sistemas de medição e representação não necessariamente demandam instrumentos de alto custo, mas que, ao contrário, reforçam a tradição do desenho. Da mesma forma, os produtos gráficos gerados se não coordenados a outras instâncias informativas e às análises críticas e interpretativas se tornam meros simulacros. Os produtos aqui apresentados servem, portanto, como base de anotação desse processo de reconhecimento cronológico, uma etapa inicial no longo processo de reconhecimento de um bem cultural.

O objeto de estudo desse trabalho apresentou condições peculiares. De um lado a escala dos edifícios e a envergadura de um trecho urbano demandou um volume grande de fotografias, que deveriam ser adequadas aos padrões do software, o que resultou na escolha da técnica mais simples e rápida de restituição fotogramétrica, a monorrestituição. De outro, havia uma série de fotografias analógicas sem possiblidade de uso de dados calibrados da câmera nem obtenção de metadados (em alguns casos, tratava-se de fotos antigas digitalizadas), o que exigia uma análise visual interpretativa e a realização de correções manuais (seja na geração das fotos retificadas, seja na vetorização). Dessa condição, do conjunto de imagens disponíveis e produzidas, uma reflexão em especial deve ser ressaltada: as imagens de arquiteturas podem ser entendidas como uma documentação por meio das quais é possível articular leituras e interpretações diversas, desde a restituição geométrica até a interpretação antropológica da paisagem, passando por aspectos de linguagens subjetivos de cunho expressivo, permitindo a criação de narrativas diversas.

\section{REFERÊNCIAS}

BLANCO, Giovanni; CAMPOS NETO, Candido Malta. Redescobrindo o Art Déco e o racionalismo clássico na arquitetura belenense. Arquitextos, São Paulo, ano 3, n. 032.08, Vitruvius, jan. 2003 Disponível em: http://www.vitruvius.com.br/revistas/read/ arquitextos/03.032/719. Acesso em: 15 abr. 2019.

BOATO, A. L'archeologia in architettura: misurazioni, stratigrafie, datazioni, restauro. Venezia: Marsilio, 2008.

BUENO, B. P. S. Por uma arqueologia da paisagem: mobilidade e enraizamento em perspectiva americana. Labor \& Engenho, v. 11, p. 242-262, 2017. Disponível em: https://periodicos.sbu.unicamp.br/ojs/index.php/labore/article/ view/8649556. Acesso em: 16 fev. 2019.

CHOAY, Françoise. A alegoria do patrimônio. São Paulo: Estação Liberdade/ Unesp, 2006.

FARIA, R. S. Ribeirão Preto, uma cidade em construção (1805-1930). O discurso da higiene, beleza e disciplina na modernização Entre Rios. São Paulo: Annablume, 2010
. Ribeirão Preto, uma cidade em construção (1805-1930): o moderno discurso da hygiene, beleza e disciplina. 2003. Dissertação (Mestrado em Filosofia e Ciências Humanas). FFLCH-Unicamp, Campinas.

. Ribeirão Preto, uma modernidade Entre Rios: higiene, beleza e progresso no discurso da metrópole do interior (1902-1930). RISCO-4. Revista de Pesquisa em Arquitetura e Urbanismo. PPGAU-EESC-USP-SAP. Risco (São Carlos), v. 4, p. 36-66, 2007. doi: https://doi.org/10.11606/issn.1984-4506. v0i4p36-50

FIGUEIRA, T. M. B. Produção social da cidade contemporânea: análise dos condomínios urbanísticos e loteamentos fechados de alto padrão do Subsetor Sul de Ribeirão Preto/SP. 2013. Dissertação (Mestrado em Arquitetura e Urbanismo) - IAU-USP, São Carlos.

FREITAS, P. M. G.; TIRELLO, R. A. A síntese gráfica no processo de projeto de restauração arquitetônica. In: ARQ.DOC 2010 - DOCUMENTAÇÃO DO PATRIMÔ- 
NIO ARQUITETÔNICO COM O USO DE TECNOLOGIAS DIGITAIS, 1., 2010, Salvador. Anais[...]. Salvador: LCAD; FAUFBA, 2010. p. 1-12.

GROETELAARS, N. J. Criação de modelos BIM a partir de "nuvens de pontos": estudo de métodos e técnicas para documentação arquitetônica. 2015. Tese (Doutorado em Arquitetura e Urbanismo) - Faculdade de Arquitetura, UFBA, Salvador.

HOMEM, M. C. N. O palacete paulistano e outras formas urbanas de morar da elite cafeeira - 1867-1918. São Paulo: WMF Martins Fontes, 2000.

ICOMOS. Carta de Veneza - Carta para a Conservação e Restauração de Monumentos e Sítios (1964). Veneza: ICOMOS, 1964. Disponível em: http://portal. iphan.gov.br/. Acesso em: 13 ago. 2018.

KOATZ, G. D.; ERWES, H. J. B.; PRADO, W.S.; BRITO, J. L. N. S. Documentação Precisa da Arquitetura Moderna - Utilização de Metodologias Tridimensionais. In: SEMINÁRIO LATINO-AMERICANO ARQUITETURA \& DOCUMENTAÇÃO, 2008, Belo Horizonte. Anais[...]. Belo Horizonte: UFMG, 2008. Disponível em: http://www.forumpatrimonio.com.br/ seer/index.php/forum_patrimonio/article/view/9. Acesso em: 15 abr. 2019.

LAGES, J. A. Ribeirão Preto revisitada. Ribeirão Preto: Nova Enfim, 2016.

LEMOS, C. Alvenaria Burguesa. 2. ed. São Paulo: Nobel, 1989.

MOTTA, L.; SILVA, M. B. R. Inventário. In: GRIECO, Bettina; TEIXEIRA, Luciano; THOMPSON, Analucia. (Org.). Dicionário IPHAN de Patrimônio Cultural. 2. ed. Rio de Janeiro/Brasília: IPHAN/ DAF/Copedoc, 2016, v. 1, p. 1-39.

PESAVENTO, S. J. Com os olhos no passado: a cidade como palimpsesto. Revista Esboços. Dossiê Cidade e Memória. n. 11. Florianópolis: UFSC, 2004. Disponível em: $\quad$ https://periodicos.ufsc.br/index. php/esbocos/article/view/334. Acesso em: 4 jun. 2018.

SANTOS, M. Por uma Geografia Nova: da Crítica da Geografia a uma Geografia Crítica. 6. ed. São Paulo: Editora da Universidade de São Paulo, 2008.

\section{A Natureza do Espaço:}

Técnica e Tempo, Razão e Emoção. 4. ed. São Paulo: Editora da Universidade de São Paulo, 2006

SUNEGA, R. A. Quarteirão Paulista: um conjunto harmônico de edifícios monumentais. Ribeirão Preto: Fundação In- stituto do Livro, 2011

TIRELLO, R. A. Registro do patrimônio arquitetônico com tecnologia multimídia: uma possiblidade de estudo crítico e restauro eletrônico de bens culturais. In: ENCONTRO REGIONAL DE EXPRESSÃO GRÁFICA, 5., 2006, Salvador. Anais[...]. Salvador: EDUFBA, 2006. p. 1-10.

VILLELA, Ana Teresa Cirigliano. Arqueologia da Arquitetura: a estratificação tridimensional do tempo. 2015. Dissertação (Mestrado em Arquitetura, Tecnologia e Cidade) - FEC - Unicamp, Campinas.

WAISMAN, M. El interior de la Historia Historiografia Arquitectónica para uso de Latinoamericanos. 2. ed. Bogotá: Escala, 1993.

VIOLLET-LE-DUC, E. E. Restauração. Série Artes \& Ofícios. São Paulo, Ateliê Editorial, 2000

ZANCHETI, S. M. et al. Da autenticidade nas cartas patrimoniais ao reconhecimento das suas dimensões na cidade. Textos para Discussão - Série 3: Identificação do Patrimônio Cultural. $\mathrm{CECl}$ : Olinda, 2008, p. 1-13. Disponível em: http://www.ct.ceci-br.org/ceci/br/ publicacoes/textos-para-discussao/347-textos-para-discussao-v-37.html. Acesso em: 13 ago. 2018.
Ana Teresa Cirigliano Villela anacirigliano.arquitetura@gmail. com

Rodrigo Luiz Minot Gutierrez rodrigolmgutierrez@outlook.com 